\title{
Growth, Photosynthesis, and Nutrient Uptake at Different Light Intensities and Temperatures in Lettuce
}

\author{
Jing Zhou \\ Key Laboratory of Modern Agricultural Equipment and Technology, \\ Ministry of Education and Jiangsu Province, Jiangsu University, \\ Zhenjiang 212013, China
}

\section{PingPing Li}

Key Laboratory of Modern Agricultural Equipment and Technology, Ministry of Education and Jiangsu Province, Jiangsu University, Zhenjiang 212013, China; and Nanjing Forestry University, Nanjing 210037, China

\section{JiZhang Wang and Weiguo Fu \\ Key Laboratory of Modern Agricultural Equipment and Technology, Ministry of Education and Jiangsu Province, Jiangsu University, Zhenjiang 212013, China}

Additional index words. chlorophyll fluorescence, nitrogen, photosynthetic, phosphorus, potassium, yield

\begin{abstract}
Light and temperature are two crucial factors affecting plant growth. Light intensities vary considerably with season and weather conditions. Reasonable light regulation at different temperatures is a key issue in environmental regulation. In this study, we determined the effects of light intensity and temperature on crop growth and development. Furthermore, we determined an optimal light value and a suitable light range at different temperatures for producing the lettuce Lactuca sativa L. Artificial climate chamber experiments were conducted at five light intensities $(100,200,350,500$, and $\left.600 \mu \mathrm{mol} \cdot \mathrm{m}^{-2} \cdot \mathrm{s}^{-1}\right)$, as well as at low $\left(15^{\circ} \mathrm{C} / 10^{\circ} \mathrm{C}\right)$, medium $\left(23^{\circ} \mathrm{C} / 18{ }^{\circ} \mathrm{C}\right)$, and high $\left(30{ }^{\circ} \mathrm{C} / 25^{\circ} \mathrm{C}\right)$ temperatures. In these experiments, we investigated the photosynthetic rate; chlorophyll fluorescence parameters; total $\mathrm{N}, \mathrm{P}$, and $\mathrm{K}$ uptake; and growth of lettuce plants. The results indicated that at a low temperature, the values of effective quantum yield of photosystem II photochemistry $\left(\Phi_{\mathrm{PSII}}\right)$, net photosynthetic rate $\left(P_{n}\right)$, stomatal conductance $\left(g_{\mathrm{S}}\right)$, and transpiration rate $\left(T_{r}\right)$-as well as those of $\mathrm{N}, \mathrm{K}$, and $\mathrm{P}$ uptake-were the highest at $350 \mu \mathrm{mol} \cdot \mathrm{m}^{-2} \cdot \mathrm{s}^{-1}$, followed by $500 \mu \mathrm{mol} \cdot \mathrm{m}^{-2} \cdot \mathrm{s}^{-1}$, which resulted in higher values for leaf number (LN), leaf area (LA), dry weight (DW), and fresh weight $(\mathrm{FW})$. At the medium temperature, the values of $\Phi_{\mathrm{PSI}}, P_{n}, g_{\mathrm{S}}$, and $T_{r}$, as well as those of $\mathrm{N}, \mathrm{K}$, and $P$ uptake were higher at 350,500 , and $600 \mu \mathrm{mol} \cdot \mathrm{m}^{-2} \cdot \mathrm{s}^{-1}$ than at other light intensities, resulting in high values for $L N, L A, D W$, and FW of lettuce plants. The LN, LA, and FW of lettuce plants were the highest at $500 \mu \mathrm{mol} \cdot \mathrm{m}^{-2} \cdot \mathrm{s}^{-1}$, whereas DW was the highest at $600 \mu \mathrm{mol} \cdot \mathrm{m}^{-2} \cdot \mathrm{s}^{-1}$. At a high temperature, lettuce plants exhibited the highest values of $F_{\mathrm{v}} / F_{\mathrm{m}}, \Phi_{\mathrm{PSII}}, P_{n}, g_{\mathrm{S}}$, and $T_{r}$, as well as those of $\mathrm{N}, \mathrm{K}$, and $\mathrm{P}$ uptake for the $500 \mu \mathrm{mol} \cdot \mathrm{m}^{-2} \cdot \mathrm{s}^{-1}$ treatment; whereas $\mathrm{LN}, \mathrm{LA}, \mathrm{FW}$, and DW were the highest at 600 $\mu \mathrm{mol} \cdot \mathrm{m}^{-2} \cdot \mathrm{s}^{-1}$. In addition, the values of $F_{\mathrm{v}} / F_{\mathrm{m}}$ indicated that lettuce plants were under stress under the following combinations: $600 \mu \mathrm{mol} \cdot \mathrm{m}^{-2} \cdot \mathrm{s}^{-1}$ at the low temperature, 100 $\mu \mathrm{mol} \cdot \mathrm{m}^{-2} \cdot \mathrm{s}^{-1}$ at the medium temperature, and $100-350 \mu \mathrm{mol} \cdot \mathrm{m}^{-2} \cdot \mathrm{s}^{-1}$ at the high temperature. Based on these results, an optimal regulation strategy for light intensity at different temperature environments was proposed for lettuce cultivars similar to $L$. sativa $\mathrm{L}$. in some regions, such as the subtropical regions of China. Specifically, for low temperatures, light intensities of 350 to $500 \mu \mathrm{mol} \cdot \mathrm{m}^{-2} \cdot \mathrm{s}^{-1}$ are recommended for production, and an intensity of $350 \mu \mathrm{mol} \cdot \mathrm{m}^{-2} \cdot \mathrm{s}^{-1}$ provides optimal supplementary light during early spring and winter in greenhouses. For medium temperatures, light intensities of 350 to $600 \mu \mathrm{mol} \cdot \mathrm{m}^{-2} \cdot \mathrm{s}^{-1}$ are recommended, and $500 \mu \mathrm{mol} \cdot \mathrm{m}^{-2} \cdot \mathrm{s}^{-1}$ is the optimal value during the middle of spring and autumn. For high temperatures, light intensities of 500 to $600 \mu \mathrm{mol} \cdot \mathrm{m}^{-2} \cdot \mathrm{s}^{-1}$ are recommended, and $600 \mu \mathrm{mol} \cdot \mathrm{m}^{-2} \cdot \mathrm{s}^{-1}$ is the optimal value of light intensity during late spring and early autumn.
\end{abstract}

Plant growth and development are affected by light, temperature, $\mathrm{CO}_{2}$ concentration, humidity, and other environmental factors. Light is a crucial environmental factor for plant growth. Light energy is captured by plants through photosynthesis to produce adenosine triphosphate (ATP) and nicotinamide adenine dinucleotide phosphate (NADPH) in light reactions. Subsequently, $\mathrm{CO}_{2}$ is fixed in the form of carbohydrates, and
$\mathrm{O}_{2}$ is produced in light-independent reactions (Tanaka et al., 2014; Walker et al., 2014). Insufficient light intensity may limit the assimilation of plant carbon and reduce the activity of carbon assimilation enzymes (Allen and Ort, 2001; Dai et al., 2009), thereby reducing the net photosynthetic rate $\left(P_{n}\right)$, effective quantum yield of photosystem II photochemistry ( $\left.\Phi_{\text {PSII }}\right)$, and electron transport rate (ETR) (Yan et al., 2013; Zheng et al., 2011). Although low light intensities increase plant height and specific leaf area, this factor reduces the leaf number (LN), leaf thickness, and yield (Dong et al., 2014; Hou et al., 2010; Steinger et al., 2003). Plants grown under high light intensities usually cannot use all the energy absorbed by their photosynthetic apparatus, and this excessive absorption of energy often reduces the efficiency of photosystems, particularly photosystem II. Photosynthetic activity is reduced by photoinhibition (Demmig-Adams and Adams, 1992; Long et al., 1994). Temperature is another crucial environmental factor affecting photosynthesis, respiration, transpiration, and water and nutrient uptake. Both high and low temperatures usually exert adverse effects on plant performance and productivity and considerably reduce plant yield and yield quality (Groom and Baker 1992; Guo et al., 2006; Percival, 2005; Ruelland and Zachowski, 2010). Owing to the interaction between light and temperature, the light saturation point and maximum photosynthetic rate of crops were reportedly difficult to attain, even at suitable temperatures (Hikosaka et al., 2006). Light and temperature interactions provide crucial information for optimizing environmental regulations under various seasonal conditions (Franklin et al., 2014; Lu et al., 2017).

Romaine lettuce (Lactuca sativa L.) is the main cultivated vegetable in greenhouses ( $\mathrm{Li}$ and Kubota, 2009). It has many desirable properties, such as a short growth cycle, low energy demands, high concentrations of minerals and biologically active compounds, and a high and stable yield (Kimura and Rodriguez-Amaya, 2003; Krrístková et al., 2008). Lettuce is a "cool season" vegetable that is usually grown during spring, autumn, and winter in subtropical areas. In greenhouses, a daily temperature between $10{ }^{\circ} \mathrm{C}$ and $30{ }^{\circ} \mathrm{C}$ can be maintained during cool periods without the use of heat sources (Jin et al., 2007; Luo et al., 2005). However, low natural light conditions are often encountered during consecutive rainy days, early spring, and winter, and high light intensity often occurs during late spring and early autumn (Wu 2011). Studies have determined the effects of different light levels, at some specified temperature ranges, on the growth, leaf nutrient content, and physiological characteristics of lettuce plants. Fu et al. (2012a, $2012 \mathrm{~b}$ ) demonstrated that at temperatures of $20^{\circ} \mathrm{C} / 16^{\circ} \mathrm{C}$ (day/night), lettuce plants under 400 and $600 \mu \mathrm{mol} \cdot \mathrm{m}^{-2} \cdot \mathrm{s}^{-1}$ exhibited high photochemical quenching (qP), ETR, and 
yield, as well as moderate nonphotochemical quenching parameter (NPQ) values, whereas those at $100 \mu \mathrm{mol} \cdot \mathrm{m}^{-2} \cdot \mathrm{s}^{-1}$ exhibited the lowest light-use efficiency and yield. Under the highest light intensity treatment $\left(800 \mu \mathrm{mol} \cdot \mathrm{m}^{-2} \cdot \mathrm{s}^{-1}\right)$, light-use efficiency was low, and the high intensity of light was observed to cause stress. Light intensities in the range of 400 to $600 \mu \mathrm{mol} \cdot \mathrm{m}^{-2} \cdot \mathrm{s}^{-1}$ are recommended to produce lettuce ( $\mathrm{Fu}$ et al., 2012a, 2012b). Fallovo et al. (2009) investigated leaf nutrient contents in lettuce plants in a greenhouse during spring and summer. They determined the total plant uptake of nitrogen $(\mathrm{N})$, potassium $(\mathrm{K})$, and magnesium $(\mathrm{Mg})$ and reported that these all (uptake) increased under strong natural radiation. The uptake of $\mathrm{N}, \mathrm{K}$, and $\mathrm{Mg}$ was significantly higher in summer by $4 \%, 20 \%$, and $15 \%$, respectively, than in plants harvested during the spring cropping season (Fallovo et al., 2009). Galieni et al. (2016) reported that low light conditions caused by artificial shading reduced the LN per plant and leaf dry biomass, regardless of growing season. The LA exhibited a greater increase under low-intensity light in the hightemperature growing season (T1) than in the low-temperature growing season (T2). In $\mathrm{T} 2$, a greater reduction of $g_{\mathrm{S}}$ occurred in response to low light than in T1 (Galieni et al., 2016). In another study, authors investigated daily variations in the photosynthetic rate of lettuce grown in a greenhouse during different seasonal and weather conditions. According to experimental data, the photosynthetic rate was low at $15{ }^{\circ} \mathrm{C}$ (in winter), even if light intensity was as high as $600 \mu \mathrm{mol} \cdot \mathrm{m}^{-2} \cdot \mathrm{s}^{-1}$. This photosynthetic rate was the same as that during the summer when the temperature was in the suitable range of 22 to $25^{\circ} \mathrm{C}$ and light intensity was as low as $200 \mu \mathrm{mol} \cdot \mathrm{m}^{-2} \cdot \mathrm{s}^{-1}$. Increasing the photosynthetic rate was difficult only if the temperature or light condition was within an appropriate range (Li et al., 2001). The growth and quality of lettuce plants were restricted by the mismatch of light and temperature conditions. Thus, while economic benefits may result from investigating the effects of light intensity at different temperatures on the physiological and growth responses of lettuce plants, research on the effect of light intensity and temperature interactions on growth and nutrient uptake in lettuce production is scarce. Hence, in this study, we determined the effects of light

Received for publication 23 Apr. 2019. Accepted for publication 30 July 2019 .

The research was supported by the Natural Science Foundation of Jiangsu Provincial Department of Education (17KJA416002), China Postdoctoral Science Foundation (2015M580400), and Jiangsu Province Postdoctoral Science Foundation (1501112B). It is funded by the Priority Academic Program Development of Jiangsu Higher Education Institutions. The manuscript was edited by Wallace Academic Editing. P.P.L. is the corresponding author. E-mail: zhoujing@ ujs.edu.cn. intensity and temperature on leaf photosynthetic characteristics; chlorophyll fluorescence parameters; total $\mathrm{N}$, phosphorus $(\mathrm{P})$, and $\mathrm{K}$ uptake; growth parameters; and yield. Furthermore, the optimum light intensities and suitable ranges for lettuce production under different temperatures were proposed. These results are expected to be applied in greenhouse climate control and used by growers to make decisions that improve crop performance.

\section{Materials and Methods}

Plant materials, growth conditions, and experimental design. Experiments were conducted in an artificial climatic chamber at Jiangsu University in China $\left(32.2^{\circ} \mathrm{N}, 119.5^{\circ} \mathrm{E}\right)$. Romaine lettuce (L. sativa L.) was selected as the experimental plant. Lettuce seeds were sown in a plug tray filled with peatbased compost (peat : vermiculite at $3: 1 ; \mathrm{v} /$ v) at a light intensity of $200 \mu \mathrm{mol} \cdot \mathrm{m}^{-2} \cdot \mathrm{s}^{-1}$ and at a temperature of $22 \pm 1{ }^{\circ} \mathrm{C} / 18 \pm 1{ }^{\circ} \mathrm{C}$ (mean \pm SD, day/night). When the seedlings had three true leaves, they were transplanted into plastic basins $(15.5 \mathrm{~cm}[\mathrm{~d}] \times 13 \mathrm{~cm}[\mathrm{~h}])$ at a density of one plant per basin. The plastic basins were filled with vinegar residue, peat, and vermiculite at a ratio of $2: 1: 1$ (by volume) with the following composition (percentage of dry matter): total N, $0.96 \%$; total P, $0.19 \%$; and total K, $0.43 \%$. A photoperiod of $12 \mathrm{~h}$, relative humidity (of air) of $60 \%$ to $70 \%$, and $\mathrm{CO}_{2}$ concentration of $400 \pm 50 \mathrm{ppm}$ were maintained throughout the experiments.

Red-blue light-emitting diode (LED) arrays (DR/W120; Philips Lighting Inc., Maarheeze, the Netherlands) and fluorescent lamps (T5-28 watt; Nonghui Biotechnology Co., Ltd., Shanghai, China) were used as light sources. The climate chamber had two cultivation shelves, each comprising three layers. The LED and fluorescent lamps were placed $35 \mathrm{~cm}$ above each layer. The spectral distribution of lamps was determined to identify light wavebands from 400 to $800 \mathrm{~nm}$ by using a field spectroradiometer (FieldSpec ${ }^{\circledR} 3$; Analytical Spectral Devices, Inc., Boulder, $\mathrm{CO}$ ), as depicted in Fig. 1. Both types of light sources exhibited energy aggregation areas at $\approx 440$ and 650 $\mathrm{nm}$. These two spectral regions are crucial for plant growth. The light intensity value of the LED was twice that of the fluorescent lamp.

Experiments were arranged in three batches as follows: Expt. 1: $30{ }^{\circ} \mathrm{C} / 25{ }^{\circ} \mathrm{C}$ (Sept. 26, 2015 to Oct. 25, 2015); Expt. 2: 23 ${ }^{\circ} \mathrm{C} / 18{ }^{\circ} \mathrm{C}$ (10 Apr. 2016 to 9 May 2016); and Expt. 3: $15{ }^{\circ} \mathrm{C} / 10{ }^{\circ} \mathrm{C}$ (5 Dec. 2016 to 5 Jan. 2017). Each experimental set comprised five light intensity levels of 100, 200, 350, 500, and $600 \mu \mathrm{mol} \cdot \mathrm{m}^{-2} \cdot \mathrm{s}^{-1}$, which were achieved by combining varying numbers of LED and fluorescent lamps on each layer of the cultivation shelves, as illustrated in Table 1 . Photosynthetic photon flux density measured at the upper extremity of plants between 6 and $18 \mathrm{~h}$ was obtained by using a quantum sensor (ZDR-24; Zeda Instrument Co., Ltd., Hangzhou, China). Each level of light level treatment housed 28 samples.

Chlorophyll fluorescence measurements. Chlorophyll fluorescence parameters were measured 2, 3, 4, and 5 weeks after transplantation using an imaging pulse amplitudemodulated fluorometer (Imaging PAM; Heinz Walz, Effeltrich, Germany); three plants were used per treatment for gas exchange measurements. Plants were dark adapted for $30 \mathrm{~min}$ before the measurement, and the upper six fully expanded leaves of lettuce plants were selected for measurements. The minimum fluorescence $\left(F_{\mathrm{o}}\right)$ and maximum fluorescence $\left(F_{\mathrm{m}}\right)$ were obtained by applying measuring light pulses at a low frequency (1 $\mathrm{Hz}$ ) from an LED and a 600-ms saturating blue pulse $(10 \mathrm{~Hz})$, respectively. The maximum PSII quantum yield $\left(F_{\mathrm{v}} / F_{\mathrm{m}}\right)$ was calculated according to the following formula: $F_{\mathrm{v}} / F_{\mathrm{m}}=$ $\left(F_{\mathrm{m}}-F_{\mathrm{o}}\right) / F_{\mathrm{m}}$. Actinic illumination $(500 \mu \mathrm{mol}$ photons $/ \mathrm{m}^{2} / \mathrm{s}$ ) was then switched on. Saturating pulses were applied at $20 \mathrm{~s}$ intervals to measure the maximum fluorescence yield during actinic illumination $\left(F_{\mathrm{m}}^{\prime}\right)$ as well as the chlorophyll fluorescence yield during actinic illumination $\left(F^{\prime}\right)$. NPQ was calculated according to the following formula: NPQ = $\left(F_{\mathrm{m}}-F_{\mathrm{m}}^{\prime}\right) / F_{\mathrm{m}}^{\prime}$. $\Phi_{\text {PSII }}$ was calculated as the quotient $\left(F_{\mathrm{m}}^{\prime}-F^{\prime}\right) / F_{\mathrm{m}}^{\prime}$ (Janka et al., 2015; Yang et al., 2018).

Gas exchange measurements. Photosynthetic characteristics were measured on the same upper six fully expanded leaves of lettuce plants in each treatment at 2, 3, 4, and 5 weeks after transplantation. Three plants were used per treatment for gas exchange measurements. The $P_{n}, g_{\mathrm{S}}$, and $T_{r}$ were measured using a portable photosynthesis instrument (LI-6400 XT; LI-COR Biosciences, Lincoln, NE) as reported previously (O'Carrigan et al., 2014). The irradiance and temperature of the leaf chamber were set according to each treatment, and results were recorded when $P_{n}$ reached a steady state. The gas exchange system allowed control of the $\mathrm{CO}_{2}$ concentration at 400 $\mu \mathrm{mol} \cdot \mathrm{m}^{-2} \cdot \mathrm{s}^{-1}$ using an integrated $\mathrm{CO}_{2}$ mixer

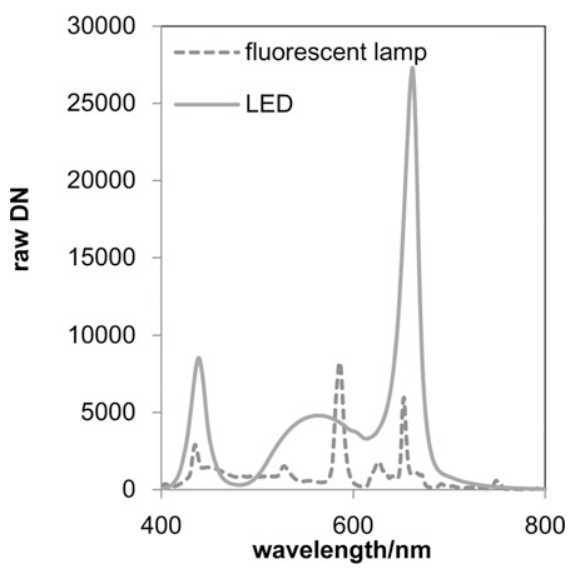

Fig. 1. Spectral distribution of the fluorescent and LED lamps. Raw digital number is obtained from the spectroradiometer. 
Table 1. Light intensity levels achieved by combining various numbers of fluorescent and LED lamps.

\begin{tabular}{|c|c|c|c|c|}
\hline Temperature day/night & Fluorescent lamps numbers & LED numbers & Light intensity $\left(\mu \mathrm{mol} \cdot \mathrm{m}^{-2} \cdot \mathrm{s}^{-1}\right)$ & Treatment symbol \\
\hline \multirow[t]{5}{*}{$15 / 10^{\circ} \mathrm{C}$} & 3 & 0 & 100 & P100-T15 \\
\hline & 0 & 3 & 200 & P200-T15 \\
\hline & 1 & 4 & 350 & $\mathrm{P} 350-\mathrm{T} 15$ \\
\hline & 5 & 4 & 500 & P500-T15 \\
\hline & 8 & 4 & 600 & P600-T15 \\
\hline \multirow[t]{5}{*}{$23 / 18^{\circ} \mathrm{C}$} & 3 & 0 & 100 & P100-T23 \\
\hline & 0 & 3 & 200 & P200-T23 \\
\hline & 1 & 4 & 350 & P350-T23 \\
\hline & 5 & 4 & 500 & P500-T23 \\
\hline & 8 & 4 & 600 & P600-T23 \\
\hline \multirow[t]{5}{*}{$30 / 25^{\circ} \mathrm{C}$} & 3 & 0 & 100 & P100-T30 \\
\hline & 0 & 4 & 200 & P200-T30 \\
\hline & 1 & 4 & 350 & P350-T30 \\
\hline & 5 & 4 & 500 & Р500-T30 \\
\hline & 8 & 4 & 600 & Р600-Т30 \\
\hline
\end{tabular}

(LI-COR Biosciences), and the flow rate was adjusted to $500 \mu \mathrm{mol} \cdot \mathrm{s}^{-1}$. All measurements were performed between 0900 and $1100 \mathrm{HR}$.

Lettuce nutrition measurements. Three plants per treatment were randomly selected and used to analyze the total N, P, and $\mathrm{K}$ content 5 weeks after transplantation. After drying, all leaves were treated with $\mathrm{H}_{2} \mathrm{SO}_{4}-\mathrm{H}_{2} \mathrm{O}_{2}$ for heat digestion. The $\mathrm{N}$ content in lettuce leaves was determined using a Continuous Flow Auto Analyzer III (AA3-HR; SEAL Analytical, Southampton, UK) at $660 \mathrm{~nm}$. The $P$ content was measured using a spectrophotometer (ultraviolet-2100; Beifen-Ruili Analytical Instrument Co., Ltd, Beijing, China), and absorbance was read at $880 \mathrm{~nm}$. The $\mathrm{K}$ content was quantified using a flame photometer (BWB-XP; BWB Technologies, Newbury, UK) in accordance with the method of a previous study (Mudau et al., 2007). The N, P, and $K$ uptake of lettuce plants were calculated by multiplying the DW of lettuce plants by their N, P, and K content, respectively.

Growth and biomass measurements. Three lettuce samples were randomly selected to count the LN and calculate LA by scanning the leaves of each plant using an LA2400 scanner. Images were then acquired using the WinFOLIA software program (Regent Instruments Inc., Quebec). At the end of each experiment, all the shoots of the lettuce plants were harvested; and the leaves were counted and weighed collectively to determine their FW, by using an electronic analytical balance with an accuracy of $0.1 \mathrm{mg}$. The DW of leaves was obtained by drying them in an oven first at $105{ }^{\circ} \mathrm{C}$ for $1 \mathrm{~h}$ and then at $80^{\circ} \mathrm{C}$ for another $72 \mathrm{~h}$.

Statistical analysis. Results are expressed as the mean \pm SD of three replicates in each of three individuals. Data were analyzed using two-way ANOVA. Multiple comparisons between treatment means were conducted using the least significant difference (LSD) test at $P<0.05$. Pearson's analysis (twotailed) was used to evaluate correlations between light intensity and the variables pertaining to the lettuces' properties. An independent (unpaired) $t$ test (two-tailed) was used to test the significance of differences between the two means $(P<0.05)$.

\section{Results and Discussion}

Chlorophyll fluorescence characteristics. $F_{\mathrm{v}} / F_{\mathrm{m}}$ was used as a sensitive indicator of the original light-energy capture efficiency of PSII reaction centers and plant health status (Wong et al., 2012; Zhang et al., 2017). High values of $F_{\mathrm{v}} / F_{\mathrm{m}}$ indicated high PSII maximum light conversion efficiencies. In healthy organisms, the $F_{\mathrm{v}} / F_{\mathrm{m}}$ value is $\approx 0.8-0.84$ in most C 3 plant species, but the value decreases significantly when plants are exposed to stress (da Silva Branco et al., 2017; Kalaji et al., 2012; Wang et al., 2004). In this study, we observed that $F_{\mathrm{v}}$ $/ F_{\mathrm{m}}$ was closely related to light intensity $(P<$ 0.05 , ANOVA $)$, temperature $(P<0.05$, ANOVA), and the interaction between light intensity and temperature $(P<0.05$, ANOVA $)$ (Fig. 2). Under the low-temperature condition, a negative correlation was observed between the $F_{\mathrm{v}} / F_{\mathrm{m}}$ value and light intensities (T15) (Pearson's $r=-0.646, P<0.05)$. The $F_{\mathrm{v}} / F_{\mathrm{m}}$ value was significantly lower at a high light intensity $\left(600 \mu \mathrm{mol} \cdot \mathrm{m}^{-2} \cdot \mathrm{s}^{-1}\right)$ than at a low light intensity $\left(100 \mu \mathrm{mol} \cdot \mathrm{m}^{-2} \cdot \mathrm{s}^{-1}\right)$. The $F_{\mathrm{v}} / F_{\mathrm{m}}$ value at $600 \mu \mathrm{mol} \cdot \mathrm{m}^{-2} \cdot \mathrm{s}^{-1}$ was the smallest, and values at 600 and $500 \mu \mathrm{mol} \cdot \mathrm{m}^{-2} \cdot \mathrm{s}^{-1}$ were below 0.80 for all four determination times. Under the low temperature condition, results indicated that the light intensities of 500 and $600 \mu \mathrm{mol} \cdot \mathrm{m}^{-2} \cdot \mathrm{s}^{-1}$ may exceed the optimal light intensity range required by lettuce plants, resulting in photoinhibition. The curves of $F_{\mathrm{v}} / F_{\mathrm{m}}$ at the five light intensity treatments were synchronous at $\mathrm{T} 15$; the highest reading was observed in week 4 (28 d after transplantation). Nevertheless, the correlations between $F_{\mathrm{v}} / F_{\mathrm{m}}$ and light intensity were positive at the medium temperature (T23) (Pearson's $r=0.610, P<0.05)$ and at the high temperature (T30) (Pearson's $r=0.908, P<0.001$ ). At T23, the dynamics of $F_{\mathrm{v}} / F_{\mathrm{m}}$ at light intensities of 350,500 , and $600 \mu \mathrm{mol} \cdot \mathrm{m}^{-2} \cdot \mathrm{s}^{-1}$ were completely consistent. All these treatments reached their respective peaks at 3 weeks, and the $F_{\mathrm{v}} / F_{\mathrm{m}}$ values were $>0.80$. The curve of $F_{\mathrm{v}} / F_{\mathrm{m}}$ at $500 \mu \mathrm{mol} \cdot \mathrm{m}^{-2} \cdot \mathrm{s}^{-1}$ was the highest, followed by the curves at 200 , 350 , and $600 \mu \mathrm{mol} \cdot \mathrm{m}^{-2} \cdot \mathrm{s}^{-1}$ for all treatment times. The $F_{\mathrm{v}} / F_{\mathrm{m}}$ value at $500 \mu \mathrm{mol} \cdot \mathrm{m}^{-2} \cdot \mathrm{s}^{-1}$ did not differ significantly from the $F_{\mathrm{v}} / F_{\mathrm{m}}$ values at 200,350 , and $600 \mu \mathrm{mol} \cdot \mathrm{m}^{-2} \cdot \mathrm{s}^{-1}$, according to the results of the $t$ test $(P>$
$0.05)$. However, the $F_{\mathrm{v}} / F_{\mathrm{m}}$ values at 100 and $200 \mu \mathrm{mol} \cdot \mathrm{m}^{-2} \cdot \mathrm{s}^{-1}$ reached their peak at 4 weeks. The $F_{\mathrm{v}} / F_{\mathrm{m}}$ values were the lowest at a light intensity of $100 \mu \mathrm{mol} \cdot \mathrm{m}^{-2} \cdot \mathrm{s}^{-1}$ and were less than 0.8 . These results indicated that photoinhibition may have occurred when light intensity was below 100 $\mu \mathrm{mol} \cdot \mathrm{m}^{-2} \cdot \mathrm{s}^{-1}$ at $\mathrm{T} 23$. Similar changes were observed at T30. The $F_{\mathrm{v}} / F_{\mathrm{m}}$ values at 100 $\mu \mathrm{mol} \cdot \mathrm{m}^{-2} \cdot \mathrm{s}^{-1}$ were the smallest, together with those for 200 and $350 \mu \mathrm{mol} \cdot \mathrm{m}^{-2} \cdot \mathrm{s}^{-1}$ treatments. $F_{\mathrm{v}} / F_{\mathrm{m}}$ values at 100,200 , and $350 \mu \mathrm{mol} \cdot \mathrm{m}^{-2} \cdot \mathrm{s}^{-1}$ were all below 0.8 . Severe stress occurred at $100 \mu \mathrm{mol} \cdot \mathrm{m}^{-2} \cdot \mathrm{s}^{-1}$, whereas mild stress occurred at 200 and $350 \mu \mathrm{mol} \cdot \mathrm{m}^{-2} \cdot \mathrm{s}^{-1}(P<0.05, t$ test $)$. However, the effects of the light intensities of 500 and $600 \mu \mathrm{mol} \cdot \mathrm{m}^{-2} \cdot \mathrm{s}^{-1}$ on $F_{\mathrm{v}} / F_{\mathrm{m}}$ were significantly different from those of low light intensities. $F_{\mathrm{v}} / F_{\mathrm{m}}$ at intensities of 500 and 600 $\mu \mathrm{mol} \cdot \mathrm{m}^{-2} \cdot \mathrm{s}^{-1}$ were higher and were all greater than 0.8 . The $F_{\mathrm{v}} / F_{\mathrm{m}}$ value was the highest at 500 $\mu \mathrm{mol} \cdot \mathrm{m}^{-2} \cdot \mathrm{s}^{-1}$ at all four determined times, indicating this light intensity is optimal for lettuce growing at T30. In addition, the curves of $F_{\mathrm{v}} / F_{\mathrm{m}}$ at the five light intensities were synchronous, and the highest reading was obtained at week 3 .

Light energy is absorbed by PSII through three pathways: photochemistry, thermal dissipation, and nonphotochemical quenching. Because those processes are competitive, the responses of the photosynthetic apparatus to different environmental conditions can be indicated by complementary changes in the yield of chlorophyll fluorescence. These responses are widely described using NPQ and $\Phi_{\text {PSII }}$ (Demmig-Adams et al., 1996; Kramer et al., 2004). NPQ measures the proportion of light energy lost through regulatory thermal dissipation, and $\Phi_{\text {PSII }}$ measures the proportion of light energy absorbed by antenna pigments in PSII used in photochemistry. In the present study, we observed that NPQ values were negatively correlated with light intensities at T15, T23, and T30 (Pearson's $r=-0.703,-0.632$, and -0.395 , respectively; all $P<0.05$ ), and $\Phi_{\mathrm{PSII}}$ was positively correlated with light intensity at T15, T23, and T30 (Pearson's $r=0.704,0.750$, and 0.808 , respectively; all $P<0.05$ ) (Fig. 3). At $\mathrm{T} 15, \mathrm{NPQ}$ values at 100 and $200 \mu \mathrm{mol} \cdot \mathrm{m}^{-2} \cdot \mathrm{s}^{-1}$ were the highest, and these values were significantly higher than those at other light 

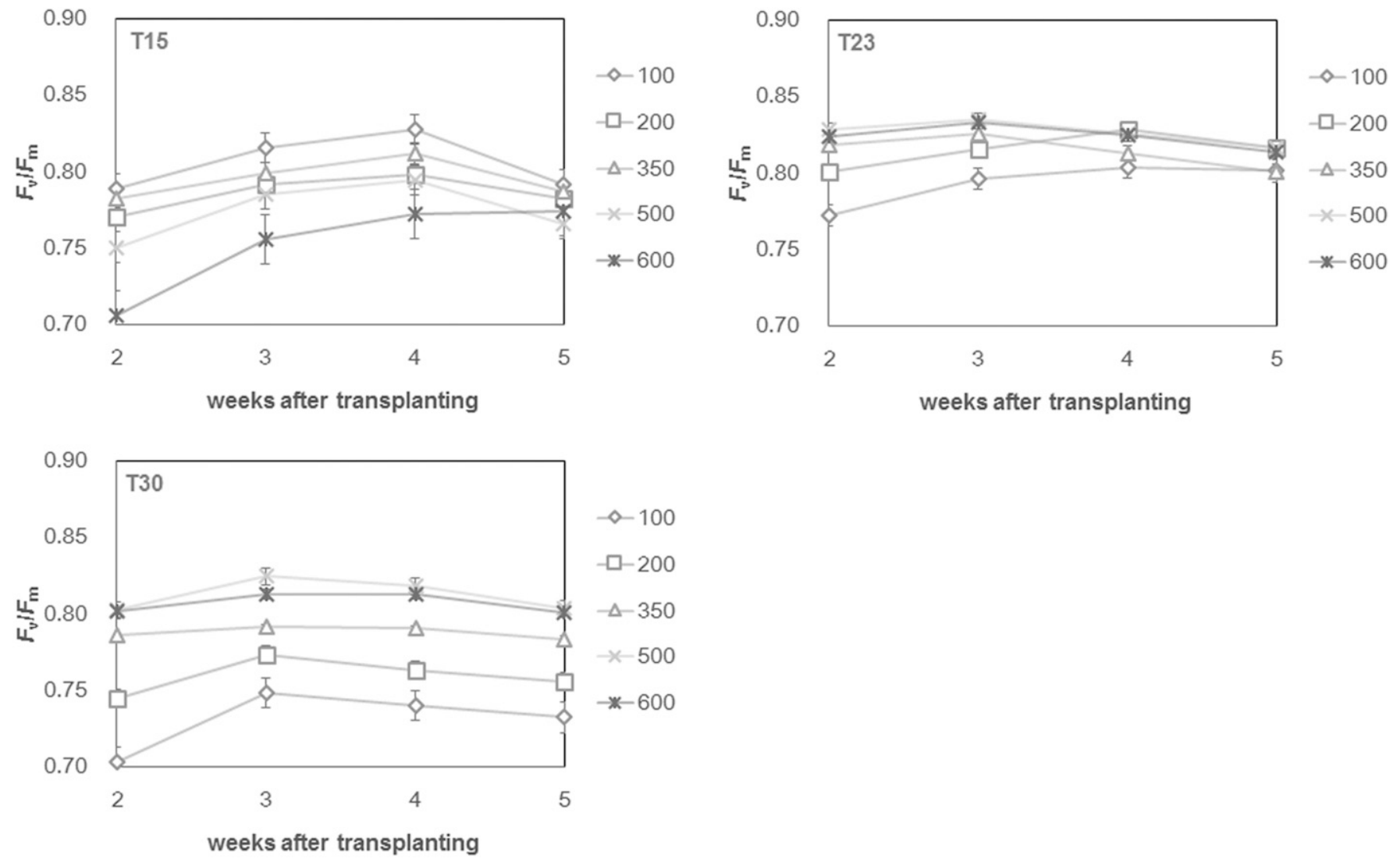

Fig. 2. Maximum PSII quantum yield $\left(F_{\mathrm{v}} / F_{\mathrm{m}}\right)$ as a function of time (weeks after transplantation) at the five light intensities $(100,200,350,500$, and 600 $\left.\mu \mathrm{mol} \cdot \mathrm{m}^{-2} \cdot \mathrm{s}^{-1}\right)$ and three temperatures $(\mathrm{T} 15, \mathrm{~T} 23$, and T30). Mean values with standard error of the mean $(\mathrm{n}=3)$.

intensity treatments $(P<0.05, t$ test $)$. However, $\Phi_{\text {PSII }}$ was the lowest at $100 \mu \mathrm{mol} \cdot \mathrm{m}^{-2} \cdot \mathrm{s}^{-1}$, followed by $200 \mu \mathrm{mol} \cdot \mathrm{m}^{-2} \cdot \mathrm{s}^{-1}$ during the treatment times (all $P<0.05, t$ test). This coincided with earlier findings that poor light with low temperature caused a decrease of photochemical efficiency by increasing the thermal deexcitation of PSII (Hovenden and Warren, 1998; Verhoeven, 2014). The $\Phi_{\text {PSII }}$ value was highest at $350 \mu \mathrm{mol} \cdot \mathrm{m}^{-2} \cdot \mathrm{s}^{-1}$, followed by $500 \mu \mathrm{mol} \cdot \mathrm{m}^{-2} \cdot \mathrm{s}^{-1}$; and no significant difference was noted between the two light intensities $(P>0.05, t$ test $)$. This result demonstrated that these plants at 350 and $500 \mu \mathrm{mol} \cdot \mathrm{m}^{-2} \cdot \mathrm{s}^{-1}$ allocated more of the absorbed light energy to photochemistry than to dissipation processes. This allocation helped the plants to optimize photosynthesis and growth. However, NPQ and $\Phi_{\text {PSII }}$ values both decreased at $600 \mu \mathrm{mol} \cdot \mathrm{m}^{-2} \cdot \mathrm{s}^{-1}$, indicating that the consumption of excess light energy decreased simultaneously through photochemical reactions and heat dissipation. Therefore, more excess light energy could be used to generate large numbers of reactive oxygen species, which aggravated photooxidative risks (Niyogi, 1999). The curves of $\Phi_{\text {PSII }}$ at 350,500 , and $600 \mu \mathrm{mol} \cdot \mathrm{m}^{-2} \cdot \mathrm{s}^{-1}$ were synchronous, with the peak at week 4 . At T23 and T30, NPQ was the highest at a light intensity of $100 \mu \mathrm{mol} \cdot \mathrm{m}^{-2} \cdot \mathrm{s}^{-1}$, and it was not significantly different from those observed at the other four light intensities $(P>0.05, t$ test $)$.

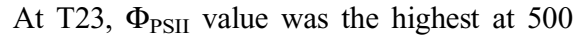

$\mu \mathrm{mol} \cdot \mathrm{m}^{-2} \cdot \mathrm{s}^{-1}$, followed by 350,600 , and 200 $\mu \mathrm{mol} \cdot \mathrm{m}^{-2} \cdot \mathrm{s}^{-1}$; and these light intensities had similar effects on the light-use efficiencies of lettuce plants. The $\Phi_{\text {PSII }}$ value at 100 $\mu \mathrm{mol} \cdot \mathrm{m}^{-2} \cdot \mathrm{s}^{-1}$ was significantly lower than those at other light intensities (all $P<0.05, t$ test). These findings are consistent with those of a previous study, which reported that a light intensity of 200 to $600 \mu \mathrm{mol} \cdot \mathrm{m}^{-2}$ $\cdot \mathrm{s}^{-1}$ was suitable for the growth of lettuce and did not result in light stress (Fu et al., 2012a). The curves of $\Phi_{\text {PSII }}$ at 350,500 , and $600 \mu \mathrm{mol} \cdot \mathrm{m}^{-2} \cdot \mathrm{s}^{-1}$ were synchronous, with the peak at week 3 , whereas those at 100 and $200 \mu \mathrm{mol} \cdot \mathrm{m}^{-2} \cdot \mathrm{s}^{-1}$ were synchronous, with the peak at week 4 . At T30, $\Phi_{\text {PSII }}$ values were relatively high at 350,500 , and 600 $\mu \mathrm{mol} \cdot \mathrm{m}^{-2} \cdot \mathrm{s}^{-1}$, and the optimum light intensity was $500 \mu \mathrm{mol} \cdot \mathrm{m}^{-2} \cdot \mathrm{s}^{-1}$. No significant differences in $\Phi_{\text {PSII }}$ were observed among the three light intensities. The $\Phi_{\text {PSII }}$ value was the lowest at $100 \mu \mathrm{mol} \cdot \mathrm{m}^{-2} \cdot \mathrm{s}^{-1}$, followed by $200 \mu \mathrm{mol} \cdot \mathrm{m}^{-2} \cdot \mathrm{s}^{-1}$. These results indicated that at $\mathrm{T} 30$, lettuce grown under light intensities of 350 to $600 \mu \mathrm{mol} \cdot \mathrm{m}^{-2} \cdot \mathrm{s}^{-1}$ more effectively used absorbed light in the photosynthetic processes than lettuce grown under low light (below $200 \mu \mathrm{mol} \cdot \mathrm{m}^{-2} \cdot \mathrm{s}^{-1}$ ). In addition, the curves of $\Phi_{\mathrm{PSII}}$ at the five light intensities were synchronous, and the highest reading was obtained at week 3 .

Photosynthetic characteristics. As detailed in Fig. 4, light intensities exerted significant effects $(P<0.05$, ANOVA) on
$P_{n}$ and exhibited strong interactions with temperature $(P<0.05$, ANOVA) during treatment. The variable $P_{n}$ was positively correlated with light intensity at all three temperatures (Pearson's $r=0.606,0.859$, and 0.913 , respectively; all $P<0.05$ ). Values of $P_{n}$ at $100 \mu \mathrm{mol} \cdot \mathrm{m}^{-2} \cdot \mathrm{s}^{-1}$ and 200 $\mu \mathrm{mol} \cdot \mathrm{m}^{-2} \cdot \mathrm{s}^{-1}$ were all lower than those at other light intensities during the treatment times. At $\mathrm{T} 15$, the $P_{n}$ values at 350 $\mu \mathrm{mol} \cdot \mathrm{m}^{-2} \cdot \mathrm{s}^{-1}$ and $500 \mu \mathrm{mol} \cdot \mathrm{m}^{-2} \cdot \mathrm{s}^{-1}$ were the highest, and values were significantly higher than that at $600 \mu \mathrm{mol} \cdot \mathrm{m}^{-2} \cdot \mathrm{s}^{-1}$ (all $P<$ $0.05, t$ test). The decrease in $P_{n}$ at 600 $\mu \mathrm{mol} \cdot \mathrm{m}^{-2} \cdot \mathrm{s}^{-1}$ was probably due to photoinhibition, as indicated by the decrease in $F_{\mathrm{v}} / F_{\mathrm{m}}$. The major reason for this photoinhibition was that the light intensity was higher than the light saturation point $(500$ $\left.520 \mu \mathrm{mol} \cdot \mathrm{m}^{-2} \cdot \mathrm{s}^{-1}\right)$, thus limiting carbon assimilation in lettuce ( $\mathrm{Li}$ and Gong, 2002). This was consistent with a previous study that revealed photoinhibition in lettuce after exposure to high light (Zhou et al., 2009). However, at T23 and T30, $P_{n}$ reached an optimum at $500 \mu \mathrm{mol} \cdot \mathrm{m}^{-2} \cdot \mathrm{s}^{-1}$ at all four determined times. At T23, no significant difference was noted among $P_{n}$ values for treatments of 350,500 , and 600 $\mu \mathrm{mol} \cdot \mathrm{m}^{-2} \cdot \mathrm{s}^{-1}$ (all $P>0.05, t$ test). The results indicated that the lettuce plants under light intensities of 350 to $600 \mu \mathrm{mol} \cdot \mathrm{m}^{-2} \cdot \mathrm{s}^{-1}$ were more efficient in using light energy, which played an important role in maximizing the 

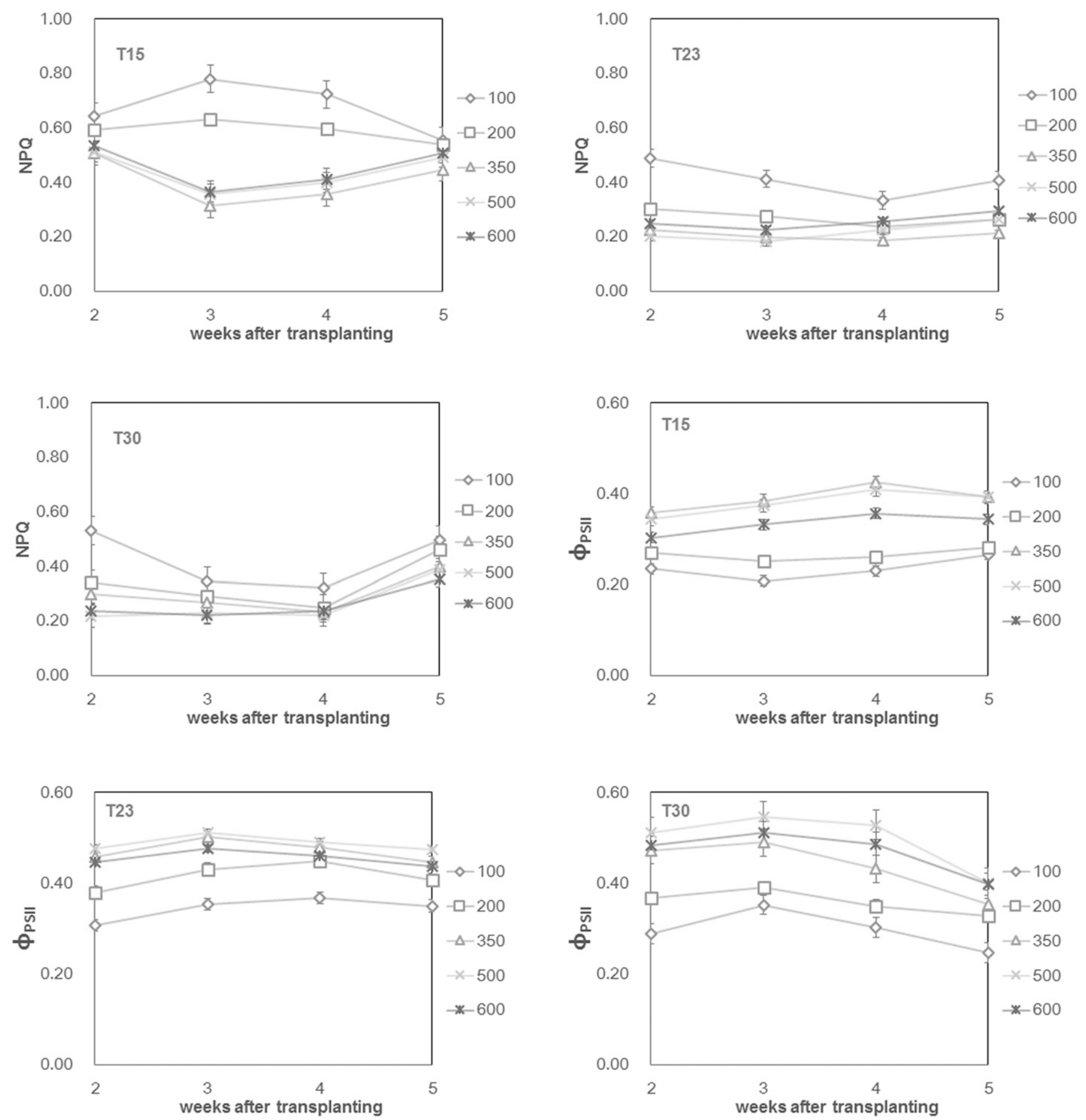

Fig. 3. Nonphotochemical quenching (NPQ) and effective quantum yield of photosystem II photochemistry $\left(\Phi_{\mathrm{PSII}}\right)$ as a function of weeks after transplantation at the five light intensity treatments $\left(100,200,350,500\right.$, and $\left.600 \mu \mathrm{mol} \cdot \mathrm{m}^{-2} \cdot \mathrm{s}^{-1}\right)$ and three temperatures $(\mathrm{T} 15, \mathrm{~T} 23$, and T30). Mean values with standard error of mean $(\mathrm{n}=3)$.

number of photoassimilates stored in the growing plant. At T30, no difference was observed between the $P_{n}$ values at 500 and $600 \mu \mathrm{mol} \cdot \mathrm{m}^{-2} \cdot \mathrm{s}^{-1}$, and they were significantly higher than $P_{n}$ at $350 \mu \mathrm{mol} \cdot \mathrm{m}^{-2} \cdot \mathrm{s}^{-1}(P<0.05, t$ test). This result demonstrated that at high temperatures, high light intensity was beneficial to maintaining high photosynthetic rates. At such rates, the quantity of Rubisco and PSII reaction center increased with the expansion of the light-harvesting complex II (Hikosaka and Terashima, 1995).

HortScience Vol. 54(11) November 2019
The $g_{\mathrm{S}}$ and the $T_{r}$ showed parallel changes with $P_{n}$ under different combinations of light intensity and temperature for all treatments. Similar to $P_{n}, g_{\mathrm{S}}$ and $T_{r}$ exhibited a significantly positive correlation with light intensity at T15, T23, and T30 (all $P<0.05$, Pearson's). This confirmed the prior finding that the effect of light intensity on photosynthesis was positively related to stomatal limitations (Fu et al., 2017).

Total uptake of $N, P$, and $K . \mathrm{N}, \mathrm{P}$, and $\mathrm{K}$ are crucial mineral elements for growing lettuce. As detailed in Table 2, light intensity exhibited a significant effect $(P<0.05$, ANOVA) on N, P, and $\mathrm{K}$ content, as well as the N, P, and $\mathrm{K}$ uptake of lettuce. It also had a strong interaction with temperature $(P<0.05$, ANOVA). $\mathrm{N}, \mathrm{P}$, and $\mathrm{K}$ content exhibited parallel changes under different combinations of light intensity and temperature. As light intensities decreased, $\mathrm{N}, \mathrm{P}$, and $\mathrm{K}$ content increased and were the highest at 100 $\mu \mathrm{mol} \cdot \mathrm{m}^{-2} \cdot \mathrm{s}^{-1}$ at each temperature. This result is consistent with the finding of a previous 

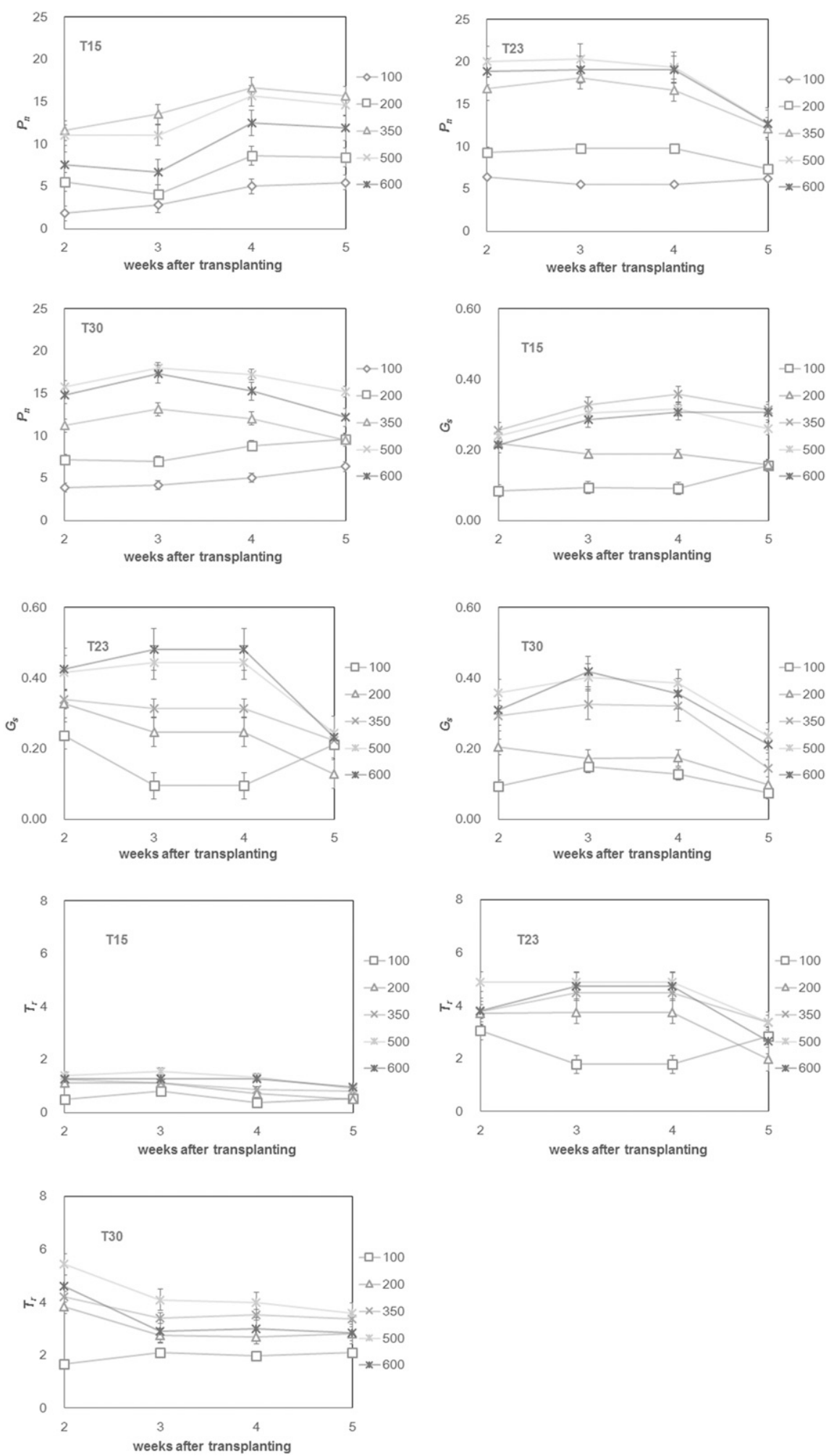

Fig. 4. Net photosynthetic rate $\left(P_{n}\right)$, stomatal conductance $\left(g_{\mathrm{S}}\right)$, and transpiration rate $\left(T_{r}\right)$ as a function of time (weeks after transplantation at five light intensities, namely 100, 200,350, 500, and 600 $\left.\mu \mathrm{mol} \cdot \mathrm{m}^{-2} \cdot \mathrm{s}^{-1}\right)$ and three temperatures $(\mathrm{T} 15, \mathrm{~T} 23$, and T30). Mean values with standard error of mean $(\mathrm{n}=3)$.

study that low light intensity markedly weakened the photosynthetic capacity of plants, resulting in a significant decrease in dry matter accumulation, thus increasing nutrient content (Kazuo and Nobutoshi, 1998). However, low light intensity reduced nutrient uptake. N, P, and $\mathrm{K}$ uptake at $100 \mu \mathrm{mol} \cdot \mathrm{m}^{-2} \cdot \mathrm{s}^{-1}$ were significantly lower than those at the other four light intensities. Nitrogen is an integral constituent of proteins, nucleic acids, and various coenzymes; and a large proportion of $\mathrm{N}$ in leaves is present in chloroplasts, with most of it being in the photosynthetic machinery (Evans, 1987). At T15, $\mathrm{N}$ uptake was highest at 350 $\mu \mathrm{mol} \cdot \mathrm{m}^{-2} \cdot \mathrm{s}^{-1}$, relatively high at 200 and 500 $\mu \mathrm{mol} \cdot \mathrm{m}^{-2} \cdot \mathrm{s}^{-1}$, and low at $600 \mu \mathrm{mol} \cdot \mathrm{m}^{-2} \cdot \mathrm{s}^{-1}$. At T23 and T30, $\mathrm{N}$ uptake was highest at 350 $\mu \mathrm{mol} \cdot \mathrm{m}^{-2} \cdot \mathrm{s}^{-1}$, followed by $500 \mu \mathrm{mol} \cdot \mathrm{m}^{-2} \cdot \mathrm{s}^{-1}$; both were significantly higher than those at 200 and $600 \mu \mathrm{mol} \cdot \mathrm{m}^{-2} \cdot \mathrm{s}^{-1}$. Light intensities of 350 to $500 \mu \mathrm{mol} \cdot \mathrm{m}^{-2} \cdot \mathrm{s}^{-1}$ at T23 and T30 markedly increased $\mathrm{N}$ uptake, a result probably associated with an increase in chlorophyll content and electron transport capacity (Evans, 1989). Phosphorus is an indispensable component in nucleic acids and plays a structural role in cellular membranes. Potassium participates in the activation of numerous enzymes required in the metabolism and transport of carbohydrates (Maathuis, 2009). At T15, P and $\mathrm{K}$ uptake at $350 \mu \mathrm{mol} \cdot \mathrm{m}^{-2} \cdot \mathrm{s}^{-1}$ were the highest, and they were slightly higher than those at 200,500 , and $600 \mu \mathrm{mol} \cdot \mathrm{m}^{-2} \cdot \mathrm{s}^{-1}$. The effect of light intensity on $\mathrm{P}$ and $\mathrm{K}$ uptake was not significant at low temperatures. However, at T23 and T30, compared with other light intensities, those of 350 and 500 $\mu \mathrm{mol} \cdot \mathrm{m}^{-2} \cdot \mathrm{s}^{-1}$ significantly enhanced $\mathrm{P}$ and $\mathrm{K}$ uptake. $\mathrm{P}$ uptake values were both the second highest at $600 \mu \mathrm{mol} \cdot \mathrm{m}^{-2} \cdot \mathrm{s}^{-1}$, and $\mathrm{K}$ uptake values were the second highest for P200-T23 and P600-T30 treatments, respectively. Regarding photosynthetic parameters, light intensity of 350 to $600 \mu \mathrm{mol} \cdot \mathrm{m}^{-2}$ $\cdot \mathrm{s}^{-1}$ at T23 and T30 caused the opening of stomata and more transpiration. Thus, the plants grew at higher rates, and the demand for $\mathrm{P}$ and $\mathrm{K}$ increased.

Plant growth and yield. As detailed in Table 3, obvious morphological differences were observed among the treatment groups. The results of the LSD multiple comparison test revealed a significant interaction effect between light intensity and temperature on the LN and LA of lettuce plants $(P<0.05)$. Low light intensity generally increases LA (Hou et al., 2010; Pires et al., 2011). However, our results differed from other studies. LA values at 100 and $200 \mu \mathrm{mol} \cdot \mathrm{m}^{-2} \cdot \mathrm{s}^{-1}$ were low among all the light intensities at three temperature levels because of the inherent photosynthetic physiological characteristics of lettuce. At T15, LA and LN at 350 and 500 $\mu \mathrm{mol} \cdot \mathrm{m}^{-2} \cdot \mathrm{s}^{-1}$ were the highest, and they were significantly higher than those at other light intensities. Although LN had no significant difference among all light intensities at T23, the LA reached highest at $500 \mu \mathrm{mol} \cdot \mathrm{m}^{-2} \cdot \mathrm{s}^{-1}$, followed by $350 \mu \mathrm{mol} \cdot \mathrm{m}^{-2} \cdot \mathrm{s}^{-1}$. This result indicates that at T23, light intensity of 350 to $500 \mu \mathrm{mol} \cdot \mathrm{m}^{-2} \cdot \mathrm{s}^{-1}$ can enhance leaf expansion, allowing plants to make better use of photosynthetic active radiation by increasing their surface area. LA and LN decreased significantly at $600 \mu \mathrm{mol} \cdot \mathrm{m}^{-2} \cdot \mathrm{s}^{-1}$, which may benefit lettuce by decreasing the exposure of plant tissues to high light intensity and reducing water loss (Matos et al., 2009). At T30, the LN and LA both increased with increasing light intensity, and they reached their highest values at $600 \mu \mathrm{mol} \cdot \mathrm{m}^{-2} \cdot \mathrm{s}^{-1}$, followed by $500 \mu \mathrm{mol} \cdot \mathrm{m}^{-2} \cdot \mathrm{s}^{-1}$. This finding showed that at T30, light intensity of 500 to 
Table 2. Effects of light intensity and temperature on nitrogen $(\mathrm{N})$, phosphorus $(\mathrm{P})$, and potassium (K) content and N, P, and K uptake in lettuce plants 5 weeks after transplantation. Mean values with standard error of mean $(\mathrm{n}=3)$. Letters indicate significant differences at $P<0.05$ according to the least significant difference test. * indicates significant difference at $P<0.05$.

\begin{tabular}{|c|c|c|c|c|c|c|}
\hline Treatment & $\mathrm{N}(\%) \pm \mathrm{SE}$ & $\mathrm{P}(\%) \pm \mathrm{SE}$ & $\mathrm{K}(\%) \pm \mathrm{SE}$ & $\mathrm{N}(\mathrm{g} /$ plant $) \pm \mathrm{SE}$ & $\mathrm{P}(\mathrm{g} / \mathrm{plant}) \pm \mathrm{SE}$ & $\mathrm{K}(\mathrm{g} /$ plant $) \pm \mathrm{SE}$ \\
\hline$\overline{\mathrm{P} 100-\mathrm{T} 15}$ & $6.45 \pm 0.25 \mathrm{a}$ & $0.74 \pm 0.02 \mathrm{a}$ & $6.06 \pm 0.15 \mathrm{a}$ & $23.17 \pm 1.58 \mathrm{~d}$ & $2.66 \pm 0.09 \mathrm{c}$ & $21.76 \pm 1.19 \mathrm{~d}$ \\
\hline P200-T15 & $5.56 \pm 0.11 \mathrm{~b}$ & $0.71 \pm 0.01 \mathrm{a}$ & $5.79 \pm 0.15 \mathrm{a}$ & $105.18 \pm 4.86 b$ & $13.45 \pm 0.6 \mathrm{ab}$ & $109.61 \pm 7.79 \mathrm{~b}$ \\
\hline P350-T15 & $5.07 \pm 0.13 \mathrm{c}$ & $0.58 \pm 0.01 \mathrm{~b}$ & $5.36 \pm 0.11 \mathrm{~b}$ & $134.55 \pm 1.49 \mathrm{a}$ & $15.51 \pm 0.25 \mathrm{a}$ & $142.21 \pm 2.72 \mathrm{a}$ \\
\hline P500-T15 & $4.42 \pm 0.09 \mathrm{~d}$ & $0.56 \pm 0.03 b$ & $5.23 \pm 0.21 \mathrm{~b}$ & $107.8 \pm 8.13 b$ & $13.6 \pm 1.11 \mathrm{ab}$ & $127.47 \pm 7.77 \mathrm{ab}$ \\
\hline P600-T15 & $3.75 \pm 0.23 \mathrm{e}$ & $0.49 \pm 0.01 \mathrm{c}$ & $5.11 \pm 0.14 \mathrm{~b}$ & $89.57 \pm 4.49 \mathrm{c}$ & $11.73 \pm 1.1 \mathrm{~b}$ & $122.24 \pm 6.9 b$ \\
\hline P100-T23 & $5.47 \pm 0.1 \mathrm{a}$ & $0.53 \pm 0.01 \mathrm{a}$ & $5.08 \pm 0.28 \mathrm{a}$ & $85.17 \pm 2.09 \mathrm{c}$ & $8.21 \pm 0.34 \mathrm{~d}$ & $79.07 \pm 3.13 \mathrm{~d}$ \\
\hline P200-T23 & $2.65 \pm 0.15 \mathrm{~b}$ & $0.37 \pm 0.01 \mathrm{~b}$ & $4.7 \pm 0.04 \mathrm{~b}$ & $105.08 \pm 6.58 \mathrm{c}$ & $14.8 \pm 0.55 \mathrm{c}$ & $186.46 \pm 2.14 b$ \\
\hline P350-T23 & $3.15 \pm 0.1 \mathrm{c}$ & $0.41 \pm 0.02 \mathrm{~b}$ & $4.43 \pm 0.25 b$ & $159.52 \pm 1.64 \mathrm{a}$ & $20.67 \pm 1.56 \mathrm{a}$ & $224.83 \pm 15.56 \mathrm{a}$ \\
\hline P500-T23 & $2.43 \pm 0.11 \mathrm{~d}$ & $0.39 \pm 0.01 \mathrm{~b}$ & $4.01 \pm 0.12 \mathrm{c}$ & $130.53 \pm 4.53 b$ & $20.84 \pm 2.4 \mathrm{a}$ & $215.56 \pm 10.01 \mathrm{a}$ \\
\hline P600-T23 & $1.64 \pm 0.05 \mathrm{e}$ & $0.31 \pm 0.01 \mathrm{c}$ & $2.9 \pm 0.04 \mathrm{~d}$ & $95.56 \pm 0.76 \mathrm{c}$ & $17.84 \pm 1.43 b$ & $168.61 \pm 6.99 \mathrm{c}$ \\
\hline P100-T30 & $5.34 \pm 0.07 \mathrm{a}$ & $0.56 \pm 0.02 \mathrm{a}$ & $5.26 \pm 0.06 \mathrm{a}$ & $35.47 \pm 0.87 \mathrm{e}$ & $3.75 \pm 0.07 \mathrm{~d}$ & $34.92 \pm 0.39 \mathrm{~d}$ \\
\hline P200-T30 & $3.56 \pm 0.34 b$ & $0.39 \pm 0.01 \mathrm{c}$ & $4.8 \pm 0.04 b$ & $59.58 \pm 5.24 \mathrm{~d}$ & $6.51 \pm 0.23 \mathrm{c}$ & $80.37 \pm 1.21 \mathrm{c}$ \\
\hline P350-T30 & $3.45 \pm 0.12 \mathrm{~b}$ & $0.49 \pm 0.01 \mathrm{~b}$ & $4.56 \pm 0.2 \mathrm{~b}$ & $160.34 \pm 4.94 \mathrm{a}$ & $22.73 \pm 0.08 \mathrm{a}$ & $212.22 \pm 9.57 \mathrm{a}$ \\
\hline P500-T30 & $2.64 \pm 0.13 \mathrm{c}$ & $0.41 \pm 0.01 \mathrm{c}$ & $4.14 \pm 0.13 \mathrm{c}$ & $133.55 \pm 7.06 b$ & $20.95 \pm 0.63 \mathrm{a}$ & $209.47 \pm 6.7 \mathrm{a}$ \\
\hline P600-T30 & $2.05 \pm 0.13 \mathrm{~d}$ & $0.26 \pm 0.01 \mathrm{~d}$ & $3.11 \pm 0.07 \mathrm{~d}$ & $107.28 \pm 4.84 \mathrm{c}$ & $13.44 \pm 0.96 \mathrm{~b}$ & $162.73 \pm 7.73 b$ \\
\hline $\mathrm{P}$ & $*$ & $*$ & $*$ & $*$ & $*$ & $*$ \\
\hline $\mathrm{T}$ & * & $*$ & $*$ & $*$ & $*$ & $*$ \\
\hline $\mathrm{P} \times \mathrm{T}$ & * & * & * & $*$ & $*$ & $*$ \\
\hline
\end{tabular}

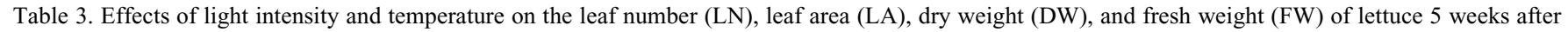
transplantation. Mean values with standard error of mean $(\mathrm{n}=3)$. Letters indicate significant differences at $P<0.05$ according to the least significant difference test. * indicates significant difference at $P<0.05$.

\begin{tabular}{|c|c|c|c|c|}
\hline Treatment & LN (per plant) & $\operatorname{LA}\left(\mathrm{cm}^{2}\right)$ & DW (g/plant) & FW (g/plant) \\
\hline$\overline{\mathrm{P} 100-\mathrm{T} 15}$ & $14.33 \pm 0.58 b$ & $202.21 \pm 7.16 \mathrm{c}$ & $0.36 \pm 0.01 \mathrm{c}$ & $7.26 \pm 0.74 \mathrm{c}$ \\
\hline P200-T15 & $16 \pm 1 \mathrm{~b}$ & $391.29 \pm 12.87 b$ & $1.89 \pm 0.12 b$ & $27.38 \pm 1.4 \mathrm{~b}$ \\
\hline P350-T15 & $21.33 \pm 0.58 \mathrm{a}$ & $613.75 \pm 12.62 \mathrm{a}$ & $2.66 \pm 0.08 \mathrm{a}$ & $47.24 \pm 3.17 \mathrm{a}$ \\
\hline P500-T15 & $20 \pm 1 \mathrm{a}$ & $553.15 \pm 28.03 \mathrm{a}$ & $2.44 \pm 0.13 \mathrm{a}$ & $43.37 \pm 0.91 \mathrm{a}$ \\
\hline P600-T15 & $17.67 \pm 0.58 b$ & $416.26 \pm 2.72 b$ & $2.39 \pm 0.18 \mathrm{a}$ & $34.92 \pm 0.78 b$ \\
\hline P100-T23 & $26 \pm 1 \mathrm{a}$ & $1292.78 \pm 23.56 \mathrm{c}$ & $1.56 \pm 0.03 \mathrm{~d}$ & $48.26 \pm 3.46 \mathrm{~d}$ \\
\hline P200-T23 & $26 \pm 1 \mathrm{a}$ & $1298.53 \pm 56 \mathrm{c}$ & $3.97 \pm 0.07 \mathrm{c}$ & $96.26 \pm 1.08 \mathrm{c}$ \\
\hline P350-T23 & $27.33 \pm 0.58 \mathrm{a}$ & $1680.5 \pm 45.87 \mathrm{a}$ & $5.07 \pm 0.12 b$ & $106.72 \pm 5.64 b$ \\
\hline P500-T23 & $27.33 \pm 1.15 \mathrm{a}$ & $1768.55 \pm 48.5 \mathrm{a}$ & $5.38 \pm 0.42 b$ & $117.03 \pm 4.87 \mathrm{a}$ \\
\hline P600-T23 & $25.67 \pm 0.58 \mathrm{a}$ & $1416.09 \pm 79.63 b$ & $5.81 \pm 0.2 \mathrm{a}$ & $113.11 \pm 2.17 \mathrm{ab}$ \\
\hline P100-T30 & $12.67 \pm 0.58 \mathrm{~d}$ & $270.83 \pm 1.28 \mathrm{c}$ & $0.66 \pm 0.01 \mathrm{~d}$ & $6.98 \pm 0.18 \mathrm{e}$ \\
\hline P200-T30 & $18 \pm 1 \mathrm{c}$ & $1184.05 \pm 54.49 \mathrm{c}$ & $1.67 \pm 0.01 \mathrm{c}$ & $45.95 \pm 5.62 \mathrm{~d}$ \\
\hline P350-T30 & $26 \pm 1 \mathrm{~b}$ & $1837.64 \pm 37.76 b$ & $4.65 \pm 0.12 b$ & $80.87 \pm 0.15 \mathrm{c}$ \\
\hline P500-Т30 & $28.67 \pm 0.58 \mathrm{a}$ & $1921.42 \pm 86.9 \mathrm{~b}$ & $5.05 \pm 0.02 \mathrm{ab}$ & $90.16 \pm 5.14 b$ \\
\hline P600-T30 & $30.67 \pm 2.52 \mathrm{a}$ & $2048.6 \pm 46.02 \mathrm{a}$ & $5.24 \pm 0.3 \mathrm{a}$ & $102.72 \pm 2.97 \mathrm{a}$ \\
\hline $\mathrm{P}$ & $*$ & * & $*$ & $*$ \\
\hline $\mathrm{T}$ & $*$ & $*$ & * & $*$ \\
\hline $\mathrm{P} \times \mathrm{T}$ & $*$ & $*$ & $*$ & $*$ \\
\hline
\end{tabular}

$600 \mu \mathrm{mol} \cdot \mathrm{m}^{-2} \cdot \mathrm{s}^{-1}$ had a greater effect on leaves formed and expansion.

Table 3 shows that the biomass of lettuce plants was significantly associated with both light intensity and the interaction between light intensity and temperature $(P<0.05)$. The DW and FW were lower under 100 and $200 \mu \mathrm{mol} \cdot \mathrm{m}^{-2} \cdot \mathrm{s}^{-1}$ at all the temperatures, indicating a lack of low light adaptive response by the lettuce plants. At $\mathrm{T} 15$, the values of DW at 350,500 , and 600 $\mu \mathrm{mol} \cdot \mathrm{m}^{-2} \cdot \mathrm{s}^{-1}$ were maintained at high levels, whereas FWs at 350 and $500 \mu \mathrm{mol} \cdot \mathrm{m}^{-2} \cdot \mathrm{s}^{-1}$ were the highest; and they were significantly higher than those at other light intensities. Similar to LN and LA, this result indicates that light intensity of 300 to $500 \mu \mathrm{mol} \cdot \mathrm{m}^{-2} \cdot \mathrm{s}^{-1}$ led to the highest photosynthetic efficiency of lettuce plants, which is optimal for lettuce growth and biomass accumulation. At T23, the DW was the highest at $600 \mu \mathrm{mol} \cdot \mathrm{m}^{-2} \cdot \mathrm{s}^{-1}$, and it was significantly higher than those at other light intensities; whereas FW at light intensities of 500 and $600 \mu \mathrm{mol} \cdot \mathrm{m}^{-2} \cdot \mathrm{s}^{-1}$ maintained high levels, and it was significantly higher than those at other light in- tensities. At T30, DW and FW increased considerably with increases in light intensity, and the highest DW and FW were obtained at a light intensity of $600 \mu \mathrm{mol} \cdot \mathrm{m}^{-2}$ $\cdot \mathrm{s}^{-1}$, followed by $500 \mu \mathrm{mol} \cdot \mathrm{m}^{-2} \cdot \mathrm{s}^{-1}$. Therefore, at medium and high temperatures, higher light intensity favored higher biomass accumulation and was most likely to cause the increase in the carbohydrates used for physiological metabolism and growth.

\section{Conclusion}

This study investigated the effects of light intensities at different temperatures on chlorophyll fluorescence; photosynthetic parameters; N, P, and K content and uptake; morphology; and yield of lettuce. Although the values of $F_{\mathrm{v}} / F_{\mathrm{m}}$ and $\mathrm{N}, \mathrm{P}$, and $\mathrm{K}$ contents were relatively higher at the light intensities of 100 and $200 \mu \mathrm{mol} \cdot \mathrm{m}^{-2} \cdot \mathrm{s}^{-1}$ at low temperatures, the values for $\Phi_{\mathrm{PSII}}, P_{n}$, and nutrient uptake (N, P, and K) were lower; and NPQ was higher than those values at 350, 500, and $600 \mu \mathrm{mol} \cdot \mathrm{m}^{-2} \cdot \mathrm{s}^{-1}$. These results indicate that the light intensities of 100 and 200 $\mu \mathrm{mol} \cdot \mathrm{m}^{-2} \cdot \mathrm{s}^{-1}$ result in lower light-use efficiency in lettuce plants because considerable light energy was dissipated in the form of NPQ. The LA, DW, and FW at 100 and 200 $\mu \mathrm{mol} \cdot \mathrm{m}^{-2} \cdot \mathrm{s}^{-1}$ were lower than those in other light intensities. In addition, compared with values at other light intensities, lettuce plants at $600 \mu \mathrm{mol} \cdot \mathrm{m}^{-2} \cdot \mathrm{s}^{-1}$ had the lowest value of $F_{\mathrm{v}} / F_{\mathrm{m}}$ and lower values of $\Phi_{\mathrm{PSII}}, P_{n}, g_{\mathrm{S}}, \mathrm{LA}$, $\mathrm{LN}, \mathrm{DW}$, and FW. The highest values of $\Phi_{\mathrm{PSII}}$; $P_{n} ; g_{\mathrm{S}} ; T_{r} ;$ and $\mathrm{N}, \mathrm{P}$, and $\mathrm{K}$ uptake were obtained at $350 \mu \mathrm{mol} \cdot \mathrm{m}^{-2} \cdot \mathrm{s}^{-1}$, followed by $500 \mu \mathrm{mol} \cdot \mathrm{m}^{-2} \cdot \mathrm{s}^{-1}$, which resulted in higher LN, LA, DW, and FW at low temperatures. At medium temperatures, lettuce plants exhibited higher values of $F_{\mathrm{v}} / F_{\mathrm{m}}$ and $\Phi_{\mathrm{PSII}}$ in the range of 200 to $600 \mu \mathrm{mol} \cdot \mathrm{m}^{-2} \cdot \mathrm{s}^{-1}$. However, $P_{n} ; \mathrm{N}$, $\mathrm{P}$, and $\mathrm{K}$ uptake; DW; and $\mathrm{FW}$ at 200 $\mu \mathrm{mol} \cdot \mathrm{m}^{-2} \cdot \mathrm{s}^{-1}$ were significantly lower than those at higher light intensities. In addition, despite the lettuce plants had low nutrient uptake in $600 \mu \mathrm{mol} \cdot \mathrm{m}^{-2} \cdot \mathrm{s}^{-1}$, DW was still the highest, while FW approached the highest value. $\Phi_{\mathrm{PSII}}, P_{n}$ and FW were the highest at $500 \mu \mathrm{mol} \cdot \mathrm{m}^{-2} \cdot \mathrm{s}^{-1}$, which indicated that a light intensity of $500 \mu \mathrm{mol} \cdot \mathrm{m}^{-2} \cdot \mathrm{s}^{-1}$ at the medium 
temperature resulted in the highest light-use efficiency of lettuce. At the high temperature, lettuce plants had the highest $F_{\mathrm{v}} / F_{\mathrm{m}}, \Phi_{\mathrm{PSII}}, P_{n}$, $g_{\mathrm{S}}, T_{r}$, nutrient uptake, and yield at 500 $\mu \mathrm{mol} \cdot \mathrm{m}^{-2} \cdot \mathrm{s}^{-1}$, followed by $600 \mu \mathrm{mol} \cdot \mathrm{m}^{-2} \cdot \mathrm{s}^{-1}$. The light-use efficiency of lettuce plants at 100,200 , and $350 \mu \mathrm{mol} \cdot \mathrm{m}^{-2} \cdot \mathrm{s}^{-1}$ was significantly lower than that at 500 and 600 $\mu \mathrm{mol} \cdot \mathrm{m}^{-2} \cdot \mathrm{s}^{-1}$. Based on these results, the following optimal light regulation strategy for different temperature conditions is proposed for lettuce cultivars, such as L. sativa L., that are grown in some regions of subtropical China. Light intensities of 350 to 500 $\mu \mathrm{mol} \cdot \mathrm{m}^{-2} \cdot \mathrm{s}^{-1}$ are recommended at low temperatures $\left(15^{\circ} \mathrm{C}\right)$. A light intensity of 350 $\mu \mathrm{mol} \cdot \mathrm{m}^{-2} \cdot \mathrm{s}^{-1}$ can optimally provide supplementary light for early spring and winter in greenhouses. Light intensities of 350 to 600 $\mu \mathrm{mol} \cdot \mathrm{m}^{-2} \cdot \mathrm{s}^{-1}$ are recommended at medium temperatures $\left(23^{\circ} \mathrm{C}\right)$. The light intensity of $500 \mu \mathrm{mol} \cdot \mathrm{m}^{-2} \cdot \mathrm{s}^{-1}$ is optimal in the middle of spring and autumn. Light intensities of 500 to $600 \mu \mathrm{mol} \cdot \mathrm{m}^{-2} \cdot \mathrm{s}^{-1}$ are recommended at high temperatures $\left(30^{\circ} \mathrm{C}\right)$. A light intensity of 600 $\mu \mathrm{mol} \cdot \mathrm{m}^{-2} \cdot \mathrm{s}^{-1}$ is optimal for late spring and early autumn.

\section{Literature Cited}

Allen, D.J. and D.R. Ort. 2001. Impacts of chilling temperatures on photosynthesis in warmclimate plants. Trends Plant Sci. 6:36-42.

da Silva Branco, M.C., A.A.F. de Almeida, Â.C. Dalmolin, D. Ahnert, and V.C. Baligar. 2017. Influence of low light intensity and soil flooding on cacao physiology. Scientia Hort. 217:243-257.

Dai, Y., Z. Shen, Y. Liu, L. Wang, D. Hannaway, and H. Lu. 2009. Effects of shade treatments on the photosynthetic capacity, chlorophyll fluorescence, and chlorophyll content of Tetrastigma hemsleyanum Diels et Gilg. Environ. Exp. Bot. 65:177-182.

Demmig-Adams, B. and W.W. Adams. 1992. Photoprotection and other responses of plants to high light stress. Annu. Rev. Plant Physiol. Plant Mol. Biol. 43:599-626.

Demmig-Adams, B., W.W. Adams, D.H. Barker, B.A. Logan, B.A. Bowling, and A.S. Verhoeven. 1996. Using chlorophyll fluorescence to assess the fraction of absorbed light allocated to thermal dissipation of excess excitation. Physiol. Plant. 98:253-264.

Dong, C., Y. Fu, G. Liu, and H. Liu. 2014. Low light intensity effects on the growth, photosynthetic characteristics, antioxidant capacity, yield and quality of wheat (Triticum aestivum L.) at different growth stages in BLSS. Adv. Space Res. 53:1557-1566.

Evans, J.R. 1987. The relationship between electron transport components and photosynthetic capacity in pea leaves grown at different light intensities. Aust. J. Plant Physiol. 14:157-170.

Evans, J.R. 1989. Photosynthesis and nitrogen relationships in leaves of $\mathrm{C} 3$ plants. Oecologia 78:9-19.

Fallovo, C., Y. Rouphael, M. Cardarelli, E. Rea, A. Battistelli, and G. Colla. 2009. Yield and quality of leafy lettuce in response to nutrient solution composition and growing season. J. Food Agr. Environ. 7:456-462.

Franklin, K.A., G. Toledo-Ortiz, D.E. Pyott, and K.J. Halliday. 2014. Interaction of light and temperature signalling. J. Expt. Bot. 65:28592871.
Fu, W., P. Li, and Y. Wu. 2012a. Effects of different light intensities on chlorophyll fluorescence characteristics and yield in lettuce. Scientia Hort. 135:45-51.

Fu, W., P. Li, Y. Wu, and J. Tang. 2012b. Effects of different light intensities on anti-oxidative enzyme activity, quality and biomass in lettuce. Hort. Sci. 39:129-134.

Fu, Y., H.Y. Li, J. Yu, H. Liu, Z.Y. Cao, N.S. Manukovsky, and H. Liu. 2017. Interaction effects of light intensity and nitrogen concentration on growth, photosynthetic characteristics and quality of lettuce (Lactuca sativa $\mathrm{L}$. var. youmaicai). Scientia Hort. 214:51-57.

Galieni, A., F. Stagnari, S. Speca, and M. Pisante. 2016. Leaf traits as indicators of limiting growing conditions for lettuce (Lactuca sativa). Ann. Appl. Biol. 169:342-356.

Groom, Q.J. and N.R. Baker. 1992. Analysis of light-induced depressions of photosynthesis in leaves of a wheat crop during the winter. Plant Physiol. 100:1217-1223.

Guo, Y.P., H.F. Zhou, and L.C. Zhang. 2006. Photosynthetic characteristics and protective mechanisms against photooxidation during high temperature stress in two citrus species. Scientia Hort. 108:260-267.

Hikosaka, K. and I. Terashima. 1995. A model of the acclimation of photosynthesis in the leaves of $\mathrm{C} 3$ plants to sun and shade with respect to nitrogen use. Plant Cell Environ. 18(6):605618.

Hikosaka, K., K. Ishikawa, A. Borjigidai, O. Muller, and Y. Onoda. 2006. Temperature acclimation of photosynthesis: Mechanisms involved in the changes in temperature dependence of photosynthetic rate. J. Expt. Bot. 57:291-302.

Hou, J.L., W.D. Li, Q.Y. Zheng, W.Q. Wang, B. Xiao, and D. Xing. 2010. Effect of low light intensity on growth and accumulation of secondary metabolites in roots of Glycyrrhiza uralensis Fisch. Biochem. Syst. Ecol. 38:160168.

Hovenden, M.J. and C.R. Warren. 1998. Photochemistry, energy dissipation and cold-hardening in eucalyptus nitens and e. pauciflora. Aust. J. Plant Physiol. 25(5):581-589.

Janka, E., O. Körner, E. Rosenqvist, and C.O. Ottosen. 2015. Using the quantum yields of photosystem II and the rate of net photosynthesis to monitor high irradiance and temperature stress in chrysanthemum (Dendranthema grandiflora). Plant Physiol. Biochem. 90:1422.

Jin, Z., S. Zhou, Y. Zhu, and D.F.T. Yuan. 2007. Characteristics of temperature and humidity in the daylight greenhouse under different weather conditions. A. Agr. Zhejiang. 19:188-191.

Kalaji, H.M., R. Carpentier, S.I. Allakhverdiev, and K. Bosa. 2012. Fluorescence parameters as early indicators of light stress in barley. $\mathrm{J}$. Photochem. Photobiol. Bol. Biol. 112:1-6.

Kazuo, Y. and S. Nobutoshi. 1998. Effect of temperature and light intensity on the growth and flowering of Odontoglossum intergeneric hybrids. J. Jpn. Soc. Hort. Sci. 67(6):619-625.

Kramer, D.M., G. Johnson, O. Kiirats, and G.E. Edwards. 2004. New fluorescence parameters for the determination of QA redox state and excitation energy fluxes. Photosynth. Res. 79:209-218.

Kimura, M. and D.B. Rodriguez-Amaya. 2003. Carotenoid composition of hydroponic leafy vegetables. J. Agr. Food Chem. 51:2603-2607. Kř́stková, E., I. Doležalová, A. Lebeda, V. Vinter, and A. Novotná. 2008. Description of morphological characters of lettuce (Lactuca sativa L.) genetic resources. Hort. Sci. (Prague) 35:113-129.

Li, P.H.Y., Y. Zhao, and H. Mao. 2001. A study on daily variation of photosynthesis in greenhouse butter-head lettuce. A. Hort. Sci. 28:240-245.

Li, Q. and C. Kubota. 2009. Effects of supplemental light quality on growth and phytochemicals of baby leaf lettuce. Environ. Exp. Bot. J. 67:59-64.

Li, Z.Z. and S.F. Gong. 2002. Vertical column and system of columnar soilless culture (SCSC) and its application to cultivation of lettuce. Chin. J. Appl. Environ. Biol. 8:142-147.

Long, S.P., S. Humphries, and P.G. Falkowski. 1994. Photoinhibition of photosynthesis in nature. Annu. Rev. Plant Physiol. 45:633-662.

Lu, T., Z. Meng, G. Zhang, M. Qi, Z. Sun, Y. Liu, and T. Li. 2017. Sub-high temperature and high light intensity induced irreversible inhibition on photosynthesis system of tomato plant (Solanum lycopersicum L.). Front. Plant Sci. 08:1-16.

Luo, W., H.F. De Zwart, I.J. Dai, X. Wang, C. Stanghellini, and C. Bu. 2005. Simulation of greenhouse management in the subtropics, Part I: Model validation and scenario study for the winter season. Biosyst. Eng. 90:307-318.

Maathuis, F. 2009. Physiological functions of mineral macronutrients. Curr. Opin. Plant Biol. 12:250-258.

Matos, F.S., R. Wolfgramm, P.C. Cavatte, F.G. Villela, M.C. Ventrella, and F.M. DaMatta. 2009. Phenotypic plasticity in response to light in the coffee tree. Environ. Exp. Bot. 67:421427.

Mudau, F.N., P. Soundy, and E.S. Du Toit. 2007. Effects of nitrogen, phosphorus, and potassium nutrition on total polyphenol content of bush tea (Athrixia phylicoides L.) leaves in shaded nursery environment. HortScience 42:334338.

Niyogi, K.K. 1999. Photoprotection revisited: Genetic and molecular approaches. Annu. Rev. Plant Physiol. Plant Mol. Biol. 50:333-359.

O'Carrigan, A., E. Hinde, N. Lu, X.Q. Xu, H. Duan, G. Huang, M. Mak, B. Bellotti, and Z.H. Chen. 2014. Effects of light irradiance on stomatal regulation and growth of tomato. Environ. Exp. Bot. 98:65-73.

Pires, M.V., A.A.F. Almeida, A.L. Figueiredo, F.P. Gomes, and M.M. Souza. 2011. Photosynthetic characteristics of ornamental passion flowers grown under different light intensities. Photosynthetica (Prague) 49(4):593-602.

Percival, G.C. 2005. The use of chlorophyll fluorescence to identify chemical and environmental stress in leaf tissue of three oak (Quercus) species. J. Arboric. 31:215-227.

Ruelland, E. and A. Zachowski. 2010. How plants sense temperature. Environ. Exp. Bot. 69:225232.

Steinger, T., B.A. Roy, and M.L. Stanton. 2003. Evolution in stressful environments II: Adaptive value and costs of plasticity in response to low light in Sinapis arvensis. J. Evol. Biol. 16:313-323.

Tanaka, Y., E. Kumagai, Y. Tazoe, S. Adachi, and K. Homma. 2014. Leaf photosynthesis and its genetic improvement from the perspective of energy flow and $\mathrm{CO}_{2}$ diffusion. Plant Prod. Sci. 17:111-123.

Walker, B.J., D.D. Strand, D.M. Kramer, and A.B. Cousins. 2014. The response of cyclic electron flow around photosystem I to changes in photorespiration and nitrate assimilation. Plant Physiol. 165(1):453-462.

Wang, B.L., M. Xu, X.H. Shi, and J.H. Cao. 2004. Effects of high temperature stress on antioxidant 
systems, chlorophyll and chlorophyll fluorescence parameters in early cauliflower leaves. Sci. Agr. Sin. 37:1245-1250.

Wong, S.L., C.W. Chen, H.W. Huang, and J.H. Weng. 2012. Using combined measurements of gas exchange and chlorophyll fluorescence to investigate the photosynthetic light responses of plant species adapted to different light regimes. Photosynthetica 50:206214.

Wu, C.C. 2011. The analysis and regionalization of climate for vegetable in protected cultivation in China. Chinese Master's Theses Full-text Database: S1. Agr. Sci. Technol. 2:1-55.
Verhoeven, A. 2014. Sustained energy dissipation in winter evergreens. New Phytol. 201(1):57-65.

Yan, N., X.F. Xu, Z.D. Wang, J.Z. Huang, and D.P. Guo. 2013. Interactive effects of temperature and light intensity on photosynthesis and antioxidant enzyme activity in Zizania latifolia Turcz. plants. Photosynthetica 51:127-138.

Yang, X., H. Xu, L. Shao, T. Li, Y. Wang, and R. Wang. 2018. Response of photosynthetic capacity of tomato leaves to different LED light wavelength. Environ. Exp. Bot. 150:161-171.

Zhang, R., Z. Kong, S. Chen, Z. Ran, M. Ye, J. Xu, C. Zhou, K. Liao, J. Cao, and X. Yan. 2017. The comparative study for physiological and bio- chemical mechanisms of Thalassiosira pseudonana and Chaetoceros calcitrans in response to different light intensities. Algal Res. 27:8998.

Zheng, Y., B. Mai, R. Wu, Y. Feng, A. Sofo, Y. Ni, J. Sun, J. Li, and J. Xu. 2011. Acclimation of winter wheat (Triticum aestivum, cv. Yangmai 13) to low levels of solar irradiance. Photosynthetica 49:426-434.

Zhou, Y.H., Y.Y. Zhang, X. Zhao, Y.Y. Yu, and K Shi. 2009. Impact of light variation on development of photoprotection, antioxidants, and nutritional value in Lactuca sativa L. J. Agr. Food Chem. 57:5494-5550. 